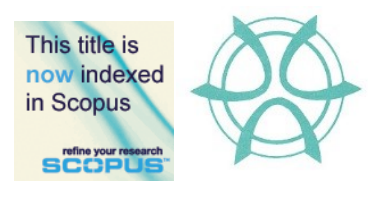

PLANNING MALAYSIA:

Journal of the Malaysian Institute of Planners

VOLUME 19 ISSUE 3 (2021), Page $249-259$

\title{
ENHANCING THE ACCURACY OF MALAYSIAN HOUSE PRICE FORECASTING: A COMPARATIVE ANALYSIS ON THE FORECASTING PERFORMANCE BETWEEN THE HEDONIC PRICE MODEL AND ARTIFICIAL NEURAL NETWORK MODEL
}

\author{
Nurul Fazira Sa' ${ }^{\prime}{ }^{1}$, Nurul Hana Adi Maimun ${ }^{2} \&$ Nurul Hazrina Idris ${ }^{3}$ \\ ${ }^{1,2}$ Centre for Real Estate Studies, Institute for Smart Infrastructure and \\ Innovative Construction, \\ UNIVERSITI TEKNOLOGI MALAYSIA \\ ${ }^{3}$ Geoscience and Digital Earth Centre, Research Institute for Sustainable \\ Environment (RISE), \\ UNIVERSITI TEKNOLOGI MALAYSIA
}

\begin{abstract}
The Hedonic Price Model (HPM), a prominent model used in real estate appraisal and economics, has been argued to be marred with nonlinearity, multicollinearity and heteroscedasticity problems that affect the accuracy of price predictions. An alternative method called Artificial Neural Network Model (ANN) was identified as capable of addressing the shortcomings of HPM and produces superior predictive performance. Hence, this study aims to evaluate the forecasting performance between HPM and ANN using Malaysian housing transaction data from the period between 2009 to 2018, sourced from the Valuation and Property Service Department, Johor Bahru. The models' performance was evaluated and compared based on their statistical and predictive performance. Results showed that ANN outperformed HPM in both statistical and predictive performance. This study benefits the expansion of academic and practical knowledge in enhancing the accuracy of house price forecasting.
\end{abstract}

Keywords: Property forecasting, property valuation, predictive accuracy, hedonic price model, artificial neural network

\footnotetext{
${ }^{1}$ Research Assistant at Universiti Teknologi Malaysia. Email: nurulfazirasaat@gmail.com
} 
Nurul Fazira Sa'at, Nurul Hana Adi Maimun \& Nurul Hazrina Idris

Enhancing the Accuracy of Malaysian House Price Forecasting: A Comparative Analysis on the Forecasting

Performance between the Hedonic Price Model (HPM) and Artificial Neural Network Model (ANN)

\section{INTRODUCTION}

The era of the fourth industrial revolution (IR 4.0) saw the explosion of new technologies such as Artificial Intelligence (AI), biotechnology, collaborative robots, internet of things, nanotechnology, quantum computing and $5 \mathrm{G}$ telecoms. All industries, including the real estate industry, are increasingly investing in advanced analytical tools to remain competitive and responsive to fast growing market demands. For instance, the application of AI in property valuation is crucial to cope with the fast changing and high demand for property valuation services (Yalpir, 2014; Sa'at and Adi Maimun, 2019b). Although AI has been explored since the 1990s, the adoption rate was slow. At present, the Hedonic Pricing Model (HPM) still dominates both literature and applications due to its flexibility and straightforwardness in estimation. Nonetheless, the nonlinearity, multicollinearity and heteroscedasticity problems (Kilpatrick, 2011; Antipov \& Pokryshevskaya, 2012; Rahman et al., 2018) that plagued HPM may cause biased estimates and specification errors that may reduce prediction accuracy (Adi Maimun, 2011). Inaccurate predictions will negatively affect the decisions of policy-makers, valuers and developers. Thus, an improved property forecasting model is vital to enhance the efficiency and accuracy of forecasting.

An AI model, known as Artificial Neural Network Model (ANN), was able to address the shortcomings of HPM (Tabales et al., 2013). Like humans, the ANN has self-learning ability, permits analysis on a large dataset, identifies relationships between variables, and predicts a future trend (Mohd Radzi et al., 2012). Despite the advantages and good forecasting performance, ANN received less attention than HPM (Mooya, 2015; Abidoye \& Chan, 2016; 2017), including its use in Malaysia. In response to the Malaysia Government's vision towards IR 4.0 through "Industry 4WRD: NATIONAL POLICY ON INDUSTRY 4.0" and to improve the accuracy of house price forecasting, this paper aims to evaluate the forecasting performance between HPM and ANN in the Malaysian context. This paper offers two benefits. Firstly, it expands academic knowledge on AIbased property forecasting. Secondly, it guides researchers, valuers and investors on AI for property valuation, index and investment.

This paper is structured as follows. An overview of the literature on house price forecasting models is provided, followed by an elaboration on the theoretical framework of HPM and ANN. Based on previous studies findings, it is hypothesised that ANN will outperform HPM in both statistical and predictive performance. The following section explains and justifies the methodology used in this study, followed by a discussion of findings.

\section{THE HPM THEORETICAL BACKGROUND}

Theoretically, HPM is executed through regression analysis (Selim, 2009). It is assumed that consumers are willing to purchase a commodity that consists of a 
bundle of property attributes to fulfil their needs and satisfaction (Limsonbunchai et al., 2004). Property attributes can be classified into locational, structural, and neighbourhood attributes and may impact property prices, either positively or negatively depending on the situation (Suhaimi et al. 2021; Zihannudin et al. 2021). Location attributes represent the geographic location of the property and access to the city centre and facilities, structural attributes represent the physical characteristics and conditions of the property while neighbourhood attributes represent the socioeconomic, local authority services, externalities and facilities of the neighbourhood where the property is located.

The following equation illustrates the house price function.

$P=f(L, S, N)$

Where $\mathrm{P}$ represents house prices, $\mathrm{L}$ represents locational attributes, $\mathrm{S}$ represents structural attributes, and $\mathrm{N}$ represents neighbourhood attributes.

Meanwhile, equation 2 below defines the general equation for HPM:

$\mathrm{Y}_{\mathrm{it}}=\beta_{0}+\beta_{1}\left(\mathrm{X}_{1} \mathrm{~m}_{1}\right)+\beta_{2}\left(\mathrm{X}_{2} \mathrm{~m}_{2}\right)+\beta 3\left(\mathrm{X}_{3} \mathrm{~m}_{3}\right)+\beta 4\left(\mathrm{X}_{\mathrm{nmn}}\right)+\varepsilon_{i}$

Where; $\mathrm{Y}_{\mathrm{it}}=$ Forecasted House Price; $\mathrm{m}=$ Price of house $\mathrm{i}$ at time period $\mathrm{t}$; $\mathrm{X}=$ Property attributes; $\beta=$ Regression coefficient; $\varepsilon_{i}=$ Error term

Despite the flexibility and simplicity of HPM, Selim (2009) argued that the HPM performance gradually decreases due to its instability in producing price coefficients. HPM is ineffective at capturing nonlinearity and is exposed to multicollinearity and heteroscedasticity problems that lead to inaccurate estimations (Limsonbunchai et al., 2004; Kilpatrick, 2011; Antipov \& Pokryshevskaya, 2012). The drawbacks of HPM also led to the application of ANN to enhance forecasting accuracy.

\section{THE HPM THEORETICAL BACKGROUND}

The ANN, which originated from McCulloch and Pitts (1943), is a computing system inspired by biological neurons that mimicked the human brain's learning process (Pagourtzi et al., 2007). In ANN, nodes represent the brain's neurons and are connected through input, hidden, and output node layers. There are four stages involved in ANN modelling, namely Input criteria (Phase 1), Data processing (Phase 2), ANN modelling (Phase 3) and Model evaluation (Phase 4) (Sa'at \& Adi Maimun, 2019a;b). The general equation for ANN is:

$\mathrm{X}_{\mathrm{jj}}=$ Total $\mathrm{W}_{\mathrm{ij}} \mathrm{Y}_{\mathrm{i}} ; \mathrm{O}_{\mathrm{j}}=\mathrm{f}\left(\mathrm{X}_{\mathrm{j}}\right)$ 
Nurul Fazira Sa'at, Nurul Hana Adi Maimun \& Nurul Hazrina Idris

Enhancing the Accuracy of Malaysian House Price Forecasting: A Comparative Analysis on the Forecasting

Performance between the Hedonic Price Model (HPM) and Artificial Neural Network Model (ANN)

Where: $X_{j}$ is the net input to artificial neuron $(j), Y_{i}$ is the value of input signal from artificial neuron (i), $\mathrm{W}_{\mathrm{ij}}$ is the weight from an artificial neuron, (i) to artificial neuron (j). $\mathrm{n}$ is the number of input signals to artificial neuron (i), $\mathrm{O}_{\mathrm{j}}$ is the output signal from artificial neuron $(\mathrm{j}), \mathrm{f}\left(\mathrm{X}_{\mathrm{j}}\right)$ is the transfer function of artificial neuron ( $\mathrm{j}$ ). Figure 1 below visualizes the neural net topology.

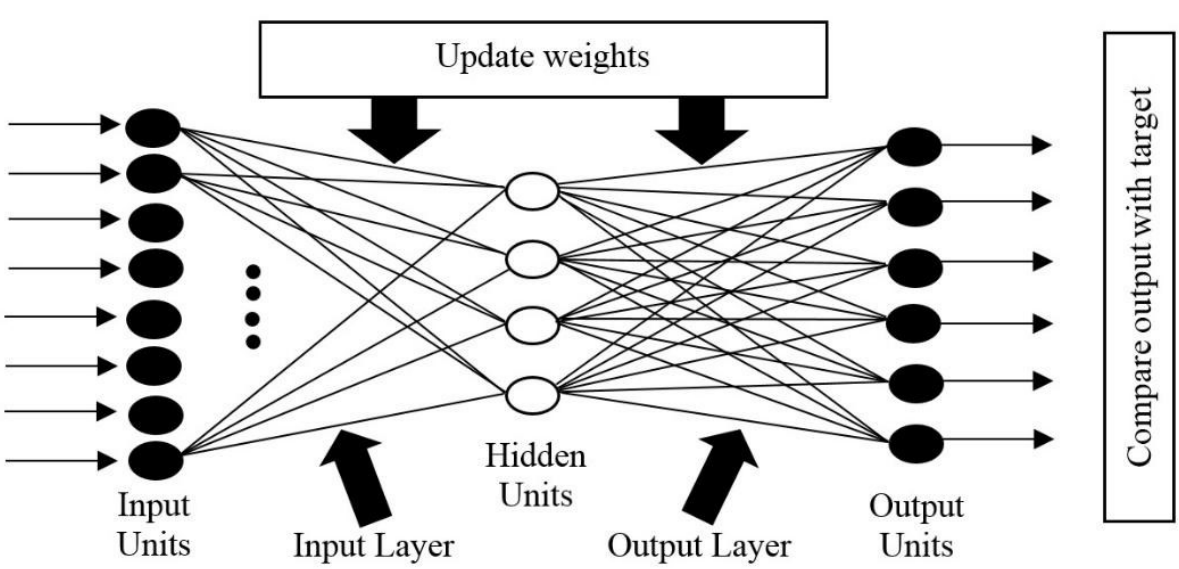

Figure 1: Neural Net Topology

The input layer, consisting of independent variables, is processed in the hidden layer(s) before being transferred to the output layer, represented as the dependent variable(s). At least one input layer, several hidden layers (s), and one output layer are required to operate ANN. The network topology is specified through a series of trials and errors to ensure no over-parameterisation and an excessive number of neurons. The back-propagation method is the most commonly used in the ANN learning algorithm. It minimises the discrepancies between actual value and forecasted value by adjusting the network's weights and biases.

\section{PREVIOUS STUDIES ON HOUSE PRICE FORECASTING}

An overview of the literature reveals that only two studies are based in Malaysia (Table 1). Most studies included locational, structural and neighbourhood attributes as independent variables due to the significant impact on house prices (De and Vupru, 2017). These variables may include main floor area, distance to facilities/amenities/city, elevator, building exteriors, garden, number of bedrooms/floors/households, population size, and type of garage/house. ANN was highlighted to be the best forecasting model based on the high $\mathrm{R}^{2}$ value compared to HPM model. Different software or tools are used to develop ANN, including NeuroShell2, Matlab and Visual Gene Developer. 
PLANNING MALAYSIA

Journal of the Malaysia Institute of Planners (2021)

Table 1: Summary of House Price Forecasting Literature

\begin{tabular}{|c|c|c|c|c|c|c|}
\hline No & $\begin{array}{c}\text { Author } \\
\text { (Year) }\end{array}$ & $\begin{array}{l}\text { Study } \\
\text { Area }\end{array}$ & Variables & Model & Software & $\mathbf{R}^{2}$ \\
\hline 1 & $\begin{array}{l}\text { Lin \& } \\
\text { Mohan } \\
(2011)\end{array}$ & USA & $\begin{array}{l}\text { Sale price, living/land area, age of } \\
\text { building, no. of bedrooms/bath } \\
\text { rooms/fireplace, external building } \\
\text { styles, location }\end{array}$ & $\begin{array}{l}\text { HPM, } \\
\text { ANN }\end{array}$ & NIL & NIL \\
\hline 2 & $\begin{array}{l}\text { Mohd } \\
\text { Radzi et al. } \\
(2012)\end{array}$ & Malaysia & $\begin{array}{l}\text { House price index, } \\
\text { employment/interest rate, } \\
\text { population, household income }\end{array}$ & ANN & $\begin{array}{l}\text { NeuroShel } \\
12\end{array}$ & 0.9932 \\
\hline 3 & $\begin{array}{l}\text { McCluskey } \\
\text { et al. } \\
(2013)\end{array}$ & Ireland & $\begin{array}{l}\text { Sale price, property size, } \\
\text { garage/property/class/glazing type, } \\
\text { no. of storey's/bedrooms, age of } \\
\text { building, property type, travel to } \\
\text { work time, location }\end{array}$ & $\begin{array}{l}\text { HPM, } \\
\text { ANN, } \\
\text { SAR, } \\
\text { GWR }\end{array}$ & NIL & $\begin{array}{l}\text { HPM: } 0.788 \\
\text { ANN: } \mathbf{0 . 8 2 3} \\
\text { SAR: } 0.887 \\
\text { GWR: } 0.879\end{array}$ \\
\hline 4 & $\begin{array}{l}\text { Morano \& } \\
\text { Tajani } \\
(2013)\end{array}$ & Italy & $\begin{array}{l}\text { Sale price, floor level, panoramic } \\
\text { view, life expectancy, heating type }\end{array}$ & $\begin{array}{l}\text { HPM, } \\
\text { ANN }\end{array}$ & NIL & $\begin{array}{l}\text { HPM: } 0.972 \\
\text { ANN: } \mathbf{0 . 9 9 9}\end{array}$ \\
\hline 5 & $\begin{array}{l}\text { Chiarazzo } \\
\text { et al. } \\
(2014)\end{array}$ & Italy & $\begin{array}{l}\text { Asking price, property size, no. of } \\
\text { bedrooms/bathrooms, improvement, } \\
\text { lift, property/construction type, } \\
\text { location, garden, beach, garage, } \\
\text { travel time, public transport, } \\
\text { neighbourhood, pollution, zone, } \\
\text { population }\end{array}$ & ANN & NIL & 0.83 \\
\hline 6 & $\begin{array}{l}\text { Ghorbani } \\
\text { \& Afgheh } \\
(2017)\end{array}$ & Iran & $\begin{array}{l}\text { Sale price, floor/land area, age of } \\
\text { building, no. of rooms, building } \\
\text { façade, lift, indoor decoration, } \\
\text { cooling system, balcony, location, } \\
\text { street width }\end{array}$ & $\begin{array}{l}\text { HPM, } \\
\text { ANN }\end{array}$ & $\begin{array}{l}\text { Eviews 6, } \\
\text { Neurosolut } \\
\text { ion5 }\end{array}$ & $\begin{array}{l}\text { HPM: } 0.88 \\
\text { ANN: } \mathbf{0 . 9 8}\end{array}$ \\
\hline 7 & $\begin{array}{l}\text { Kitapci et } \\
\text { al. } \\
(2017)\end{array}$ & Turkey & $\begin{array}{l}\text { Sale price, floor size, no. of } \\
\text { rooms/bathrooms, no. of floor, } \\
\text { parking, age of building, lift, } \\
\text { heating/property/floor type location, } \\
\text { insulation, kitchen cabinet }\end{array}$ & ANN & Matlab & NIL \\
\hline 8 & $\begin{array}{l}\text { Abidoye \& } \\
\text { Chan } \\
(2019)\end{array}$ & Nigeria & $\begin{array}{l}\text { Price index, population, real gross } \\
\text { domestic product, domestic } \\
\text { export/import, household } \\
\text { size/income/stock, } \\
\text { interest/inflation/unemployment } \\
\text { rate }\end{array}$ & $\begin{array}{l}\text { SVM, } \\
\text { ANN, } \\
\text { ARIMA }\end{array}$ & $\begin{array}{c}\text { Eviews } 9.5 \\
\text { R }\end{array}$ & $\begin{array}{l}\text { SVM: } 0.94 \\
\text { ANN: 0.92 } \\
\text { ARIMA: } \\
0.73\end{array}$ \\
\hline 9 & $\begin{array}{l}\text { Rahman et } \\
\text { al. (2018) }\end{array}$ & Malaysia & $\begin{array}{l}\text { Sale price, land area, main floor } \\
\text { area, location, transaction year }\end{array}$ & ANN & $\begin{array}{c}\text { Visual } \\
\text { Gene } \\
\text { Developer }\end{array}$ & NIL \\
\hline
\end{tabular}

\section{RESEARCH METHODOLOGY}

Over 4,000 sale observations between 2009 and 2018 in Johor Bahru were sourced from the Valuation and Property Services Department Johor Bahru. The dataset included a wealth of attributes influential to house prices such as location, land area, main floor area, type of lot and type of tenure. To ensure no outliers, several observations were removed from the dataset based on the following rule of thumb: (1) invalid number of land lots, (2) redundant data, (3) no land area, (4) sales 
Nurul Fazira Sa'at, Nurul Hana Adi Maimun \& Nurul Hazrina Idris

Enhancing the Accuracy of Malaysian House Price Forecasting: A Comparative Analysis on the Forecasting

Performance between the Hedonic Price Model (HPM) and Artificial Neural Network Model (ANN)

transaction below RM80,000.00, (5) sales transaction above RM800,000.00 and (6) incomplete or confusing information. The finalised set of data for analysis contained 3,732 observations.

A total of 21 variables, including ten years of sales transaction data, four different mukims, two types of tenure, three types of lot, land area, and main floor area were used as inputs. A feed-forward structure with only one and two hidden layer(s) was tested based on its Root Mean Square Error (RMSE) value. Contrary to previous studies, this study used RMSE rather than R2 to evaluate the model's predictive performance because it better reflects its performance in generalising the dataset. Higher estimation accuracy relates to lower RMSE value. Meanwhile, the Back Propagation Algorithm is used to train the Neural Network. IBM SPSS is applied to execute both HPM and ANN. Figure 2 illustrates the ANN designed model for this study.

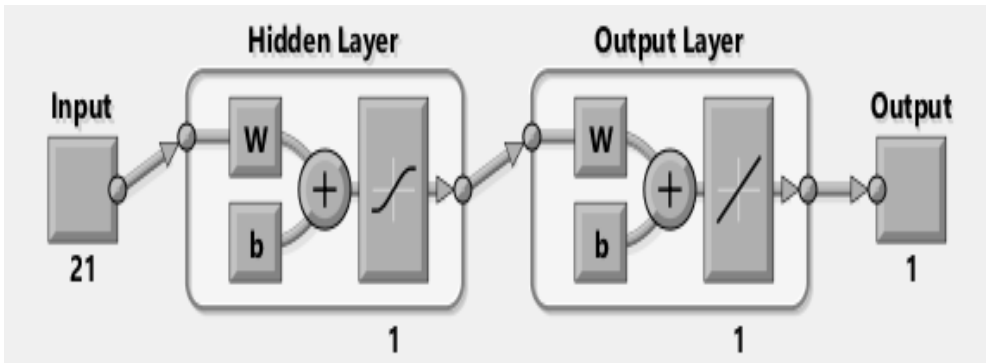

Figure 2: ANN Designed Model

Datasets were divided into three sets, namely the training set (60\%), testing set (30\%) and validation set $(10 \%)$. The number of hidden neurons were identified randomly by performing a series of trial and error process. Hidden neurons were gradually increased for each training and testing process to minimise the error between actual and forecasted prices. The number of cycles for processing datasets depended on the epochs (stopped once it reached the local minimum). ANN is designed to undergo two phases. The first phase is training an ANN where the model would learn by itself to find the unknown implicit function in forecasting house prices.

Housing data from years 2009 to 2017 were used to find the unknown function.

$\mathrm{Y}=\mathrm{mx}+\mathrm{c}$

Where: $\mathrm{Y}=$ forecasted house prices, $\mathrm{m}=$ gradient, $\mathrm{x}=$ property attributes (inputs), and $\mathrm{c}=$ biases.

After the unknown implicit function is determined, the simulation phase occurs. This is the phase where the implicit function is used to forecast house prices 
using the finalised dataset. In the simulation phase, only the 2018 year dataset is used. The forecasted values produced by ANN and HPM are compared.

\section{RESULTS AND DISCUSSION}

The ANN learning and momentum rates were performed through simultaneous trial and error processes. This training process involved 32 sets of data that varied in partition and activation function (hidden and output layers). The training algorithm used for the trial and error processes is Levenberg-Marquardt (trainmlm). The predictive performance of each set is evaluated through RMSE. The dataset with the lowest RMSE value indicates the highest prediction accuracy. Table 2 illustrates dataset number 4 with a data partitioning ratio 60:30:10, and sigmoid for activation function in hidden and output layers produced the lowest RMSE value. This indicated that the configuration for set number 4 produced the best predictive performance. Hence, set number 4 was selected to compare with RMSE value produced by HPM.

Table 2: Ranking for Testing 32 Datasets with Varying Activation Function and Different

\begin{tabular}{|c|c|c|c|c|c|c|c|}
\hline Set & $\begin{array}{c}\text { No of } \\
\text { Hidden } \\
\text { Layer }\end{array}$ & $\begin{array}{c}\text { Data } \\
\text { Partitionin } \\
\text { g }\end{array}$ & $\begin{array}{c}\text { Activation } \\
\text { Function in Hidden } \\
\text { Layer }\end{array}$ & $\begin{array}{c}\text { Activation } \\
\text { Function in } \\
\text { Output Layer }\end{array}$ & MSE & RMSE & $\begin{array}{c}\operatorname{Ran} \\
\mathbf{k}\end{array}$ \\
\hline 1 & 1 & $70: 15: 15$ & Sigmoid & Sigmoid & 0.0013 & 0.0361 & 5 \\
\hline 2 & 1 & $70: 20: 10$ & Sigmoid & Sigmoid & 0.0013 & 0.0361 & 6 \\
\hline 3 & 1 & $60: 20: 20$ & Sigmoid & Sigmoid & 0.0013 & 0.0361 & 7 \\
\hline 4 & 1 & $60: 30: 10$ & Sigmoid & Sigmoid & 0.0020 & 0.0047 & 1 \\
\hline 5 & 1 & $70: 15: 15$ & Hyperbolic-Tangent & Hyperbolic-Tangent & 0.0042 & 0.0648 & 19 \\
\hline 6 & 1 & $70: 20: 10$ & Hyperbolic-Tangent & Hyperbolic-Tangent & 0.0053 & 0.0728 & 23 \\
\hline 7 & 1 & $60: 20: 20$ & Hyperbolic-Tangent & Hyperbolic-Tangent & 0.0054 & 0.0735 & 24 \\
\hline 8 & 1 & $60: 30: 10$ & Hyperbolic-Tangent & Hyperbolic-Tangent & 0.0083 & 0.0911 & 31 \\
\hline 9 & 2 & $70: 15: 15$ & Sigmoid & Sigmoid & 0.0010 & 0.0316 & 2 \\
\hline 10 & 2 & $70: 20: 10$ & Sigmoid & Sigmoid & 0.0015 & 0.0387 & 13 \\
\hline 11 & 2 & $60: 20: 20$ & Sigmoid & Sigmoid & 0.0013 & 0.0361 & 8 \\
\hline 12 & 2 & $60: 30: 10$ & Sigmoid & Sigmoid & 0.0022 & 0.0469 & 16 \\
\hline 13 & 2 & $70: 15: 15$ & Hyperbolic-Tangent & Hyperbolic-Tangent & 0.0036 & 0.0600 & 17 \\
\hline 14 & 2 & $70: 20: 10$ & Hyperbolic-Tangent & Hyperbolic-Tangent & 0.0056 & 0.0748 & 25 \\
\hline 15 & 2 & $60: 20: 20$ & Hyperbolic-Tangent & Hyperbolic-Tangent & 0.0058 & 0.0762 & 28 \\
\hline 16 & 2 & $60: 30: 10$ & Hyperbolic-Tangent & Hyperbolic-Tangent & 0.0085 & 0.0922 & 32 \\
\hline 17 & 1 & $70: 15: 15$ & Hyperbolic-Tangent & Sigmoid & 0.0010 & 0.0316 & 3 \\
\hline 18 & 1 & $70: 20: 10$ & Hyperbolic-Tangent & Sigmoid & 0.0014 & 0.0374 & 12 \\
\hline 19 & 1 & $60: 20: 20$ & Hyperbolic-Tangent & Sigmoid & 0.0013 & 0.0361 & 9 \\
\hline
\end{tabular}


Nurul Fazira Sa'at, Nurul Hana Adi Maimun \& Nurul Hazrina Idris

Enhancing the Accuracy of Malaysian House Price Forecasting: A Comparative Analysis on the Forecasting

Performance between the Hedonic Price Model (HPM) and Artificial Neural Network Model (ANN)

\begin{tabular}{cccccccc}
20 & 1 & $60: 30: 10$ & Hyperbolic-Tangent & Sigmoid & 0.0021 & 0.0458 & 15 \\
21 & 1 & $70: 15: 15$ & Sigmoid & Hyperbolic-Tangent & 0.0043 & 0.0656 & 20 \\
22 & 1 & $70: 20: 10$ & Sigmoid & Hyperbolic-Tangent & 0.0058 & 0.0762 & 27 \\
23 & 1 & $60: 20: 20$ & Sigmoid & Hyperbolic-Tangent & 0.0053 & 0.0728 & 23 \\
24 & 1 & $60: 30: 10$ & Sigmoid & Hyperbolic-Tangent & 0.0078 & 0.0883 & 29 \\
25 & 2 & $70: 15: 15$ & Hyperbolic-Tangent & Sigmoid & 0.0012 & 0.0346 & 4 \\
26 & 2 & $70: 20: 10$ & Hyperbolic-Tangent & Sigmoid & 0.0013 & 0.0361 & 10 \\
27 & 2 & $60: 20: 20$ & Hyperbolic-Tangent & Sigmoid & 0.0013 & 0.0361 & 11 \\
28 & 2 & $60: 30: 10$ & Hyperbolic-Tangent & Sigmoid & 0.0020 & 0.0447 & 14 \\
29 & 2 & $70: 15: 15$ & Sigmoid & Hyperbolic-Tangent & 0.0038 & 0.0616 & 18 \\
30 & 2 & $70: 20: 10$ & Sigmoid & Hyperbolic-Tangent & 0.0046 & 0.0678 & 21 \\
31 & 2 & $60: 20: 20$ & Sigmoid & Hyperbolic-Tangent & 0.0060 & 0.0775 & 28 \\
32 & 2 & $60: 30: 10$ & Sigmoid & Hyperbolic-Tangent & 0.0081 & 0.0900 & 30 \\
\hline
\end{tabular}

Table 3 tabulates the statistical performance for HPM and ANN based on their MSE and RMSE values. ANN produced lower MSE (0.0020) and RMSE (0.0047) compared to HPM. This means ANN produced a more accurate prediction closer to the actual house prices than HPM.

Table 3: Statistical Performance of HPM and ANN

\begin{tabular}{ccc}
\hline Forecasting Model & MSE & RMSE \\
\hline HPM & 0.0024 & 0.0490 \\
ANN & $\mathbf{0 . 0 0 2 0}$ & $\mathbf{0 . 0 0 4 7}$ \\
\hline
\end{tabular}

At the simulation phase, an analysis was performed on ten latest transactions in 2018 to identify the best model that predicts the closest to the real market (Table 4). Overall, ANN outperformed HPM as it produced values closer to the actual price, reflected in lower error values. Nonetheless, specific prediction values deviated more than $10 \%$ from the actual value.

Table 4: Predictive Performance of HPM and ANN for 2018 House Prices

\begin{tabular}{ccccccc}
\hline $\begin{array}{c}\text { Actual } \\
\text { Price } \\
(\text { RM) }\end{array}$ & $\begin{array}{c}\text { Forecasted } \\
\text { Price (RM) }\end{array}$ & $\begin{array}{c}\text { Error } \\
(\mathbf{R M )}\end{array}$ & $\begin{array}{c}\text { Error } \\
(\mathbf{\%})\end{array}$ & $\begin{array}{c}\text { Forecasted } \\
\text { Price (RM) }\end{array}$ & $\begin{array}{c}\text { Error } \\
(\mathbf{R M )}\end{array}$ & $\begin{array}{c}\text { Error } \\
(\%)\end{array}$ \\
\hline 655000 & 480448 & -174552 & 26.65 & 498549 & -156451 & 23.89 \\
550000 & 619236 & 69236 & -12.59 & 638182 & 88182 & -16.03 \\
708000 & 551493 & -156507 & 22.11 & 587877 & -120123 & 16.97 \\
518000 & 512399 & -5601 & $\mathbf{1 . 0 8}$ & 514311 & -3689 & 0.71 \\
500000 & 639971 & 139971 & -27.99 & 645406 & 145406 & -29.08 \\
600000 & 534735 & -65265 & 10.88 & 572759 & -27241 & 4.54 \\
480000 & 499150 & 19150 & -3.99 & 528329 & 48329 & -10.07
\end{tabular}


Journal of the Malaysia Institute of Planners (2021)

\begin{tabular}{lllllll}
642000 & 615268 & -26732 & 4.16 & 636276 & -5724 & 0.89 \\
550000 & 516811 & -33189 & 6.03 & 549103 & -897 & $\mathbf{0 . 1 6}$ \\
560000 & 508934 & -51066 & 9.12 & 511145 & -48855 & 8.72 \\
\hline
\end{tabular}

A total of 364 sales transactions in 2018 were utilised to visualise the discrepancies between the actual value and predicted value (HPM and ANN) (Figure 3 ). The closer the forecasted house price trend line with the actual sale price, the more accurate the forecasting model predicts house prices. Figure 3 depicts that the ANN line trend (indicated by grey line) is closer to the actual sale price trend than the HPM model's price trend. This proved that ANN produced a more accurate estimation compared to the traditional forecasting model, which is HPM.

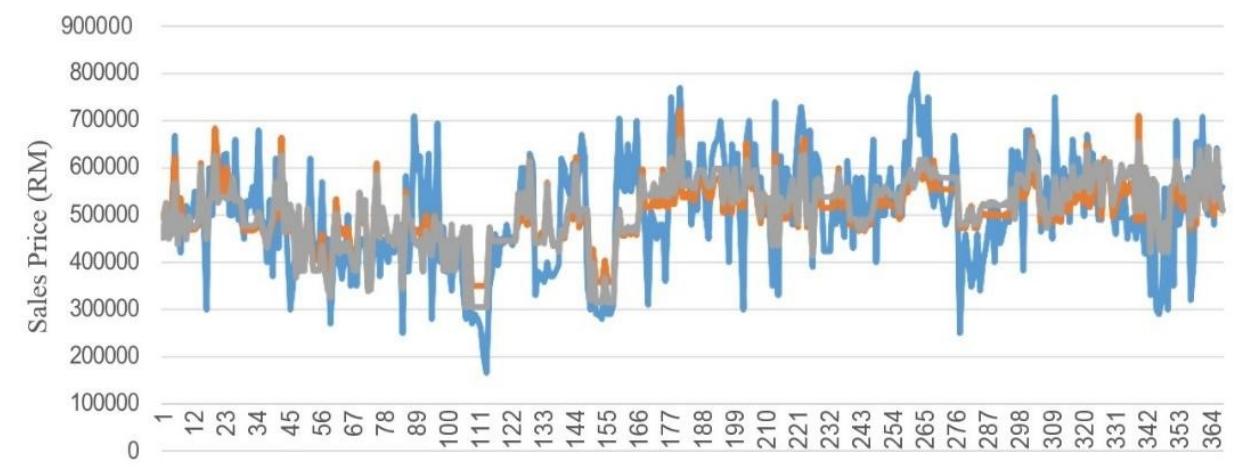

No. of Sales Transactions

Figure 3: House Price Trend for Sales Transaction in 2018

\section{CONCLUSION}

This paper evaluated the forecasting performance of HPM and ANN using house sales data. Overall, neural network algorithm set 4 with only one hidden layer - using Sigmoid as the activation function for hidden and output layers is the most appropriate algorithm for forecasting Malaysian house prices. As hypothesised, ANN outperformed HPM in forecasting performance as measured through lower RMSE. This supported the findings of McCluskey et al. (2013), Ghorbani and Afgheh (2017) and Abidoye and Chan (2018). Nonetheless, several ANN error values are more than $10 \%$, which might be caused by the omission of other price-influential variables in the model. This study expanded existing knowledge by shedding light on the forecasting performance between HPM and ANN. Academics and practitioners can use the study findings to choose the best model and technique to forecast house prices. Although good forecasting performance was observed for ANN, it is suggested that 
Nurul Fazira Sa'at, Nurul Hana Adi Maimun \& Nurul Hazrina Idris

Enhancing the Accuracy of Malaysian House Price Forecasting: A Comparative Analysis on the Forecasting

Performance between the Hedonic Price Model (HPM) and Artificial Neural Network Model (ANN)

future studies consider additional variables to improve forecasting accuracy. Future research may also explore other AI models such as autoregression, autoregressive integrated moving average, fuzzy logic, support vector machine and spatial-temporal models to uncover the potential of AI in forecasting house prices in specific and real estate as a whole.

\section{ACKNOWLEDGEMENTS}

The Ministry of Higher Education Malaysia supported this work through the Fundamental Research Grant Scheme (FRGS/1/2019/SS08/UTM/02/7). The authors also appreciate the reviewers for their constructive comments.

\section{REFERENCES}

Abd. Rahman, S.N., Adi Maimun, N.H., Razali, M.N. \& Ismail, S. (2019). The artificial neural network model (ANN) for Malaysian housing market analysis. Planning Malaysia, 17(1), 1-9.

Abidoye, R.B., \& Chan, A.P.C. (2016). A survey of property valuation approaches in Nigeria. Property Management, 34(5), 364-382.

Abidoye, R.B., \& Chan, A.P.C. (2017). Artificial neural network in property valuation: application framework and research trend. Property Management, 35(5), 554-571.

Adi Maimun, N.H. (2011). Spatiotemporal autoregressive model for Malaysian housing market analysis (Master's Thesis). Universiti Teknologi Malaysia.

Adi Maimun, N.H., Ismail, S., Junainah, M., Razali, M.N., Tarmidi, M.Z., \& Idris, N.H. An integrated framework for affordable housing demand projection and site selection. IOP Conference Series: Earth and Environmental Science, 169, 1-8.

Antipov, E.A., \& Pokryshevskaya, E.B. (2012). Mass appraisal of residential apartments: an application of random forest for valuation and a CART-based approach for model diagnostics. Expert Systems with Applications, 39(2), 1772-1778.

Chiarazzo, V., Caggiani, L., Marinelli, M. \& Ottomanelli, M. (2014). A neural network-based model for real estate price estimation considering environmental quality of property location. Transportation Research Procedia, 3(2014), 810-817.

De, U.K., \& Vupru, V. (2017). Location and neighbourhood conditions for housing choice and its rental value: empirical examination in an urban area of North-East India. International Journal of Housing Markets and Analysis, 10(4), 519-538.

Ghorbani, S. and Afgheh, S.M. (2017). Forecasting the house price for Ahvaz City: the comparison of the hedonic and artificial neural network models. Urban Economics and Management, 5(3), 29-45.

Idris, N.H., \& Masrol, N.S. (2018). Seamless transition of altimetric retracked sea levels using neural network technique: case study using simulated data. IOP Conference Series: Earth and Environmental Science, 169(1), 1-8.

Kilpatrick, J. (2011). Expert systems and mass appraisal. Journal of Property Investment \& Finance, 29(4/5), 529-550.

Kitapci, O., Tosun, Ö., Tuna, M.F. \& Turk, T. (2017). The use of artificial neural networks (ann) in forecasting housing prices in Ankara, Turkey. Journal of Marketing and Consumer Behaviour in Emerging Markets, 1(5), 4-14. 
Limsombunchai, V., Gan, C., \& Lee, M. (2004). House price prediction: hedonic price model vs artificial neural network. American Journal of Applied Sciences, 1(3), 193- 201.

Lin, C.C., \& Mohan, S.B. (2011). Effectiveness comparison of the residential property mass appraisal methodologies in the USA. International Journal of Housing Markets and Analysis, 4(3), 224-243.

McCluskey, W.J., McCord, M., Davis, P.T., Haran, M. \& McIlhatton, D. (2013). Prediction accuracy in mass appraisal: a comparison of modern approaches, Journal of Property Research, 30(4), 239-265.

McCulloch, W.S. \& Pitts, W. (1943): A logical calculus of the ideas immanent in nervous activity. Bulletin of Mathematical Biophysics, 5, 115-133.

Mohd Radzi, M.S., Muthuveerappan, C., Kamarudin, N., \& Mohammad, I.S. (2012). Forecasting house price index using artificial neural network. International Journal of Real Estate Studies, 7(1), 43-48.

Mooya, M.M. (2015). The education and professional practice of values in South Africa: a critical review. Property Management, 33(3), 245-274.

Morano, P. \& Tajani, F. (2013). Bare ownership evaluation. Hedonic price model vs. artificial neural network. International Journal of Business Intelligence and Data Mining, 8(4), 340-362.

Pagourtzi, E., Metaxiotis, K., Nikolopoulos, K. Giannelos, K. \& Assimakopoulos, V. (2007). Real estate valuation with artificial intelligence approaches. International Journal of Intelligent Systems Technologies and Applications, 2(1), 50-57.

Sa'at, N.F. \& Adi Maimun, N.H. (2019a). Artificial neural network modelling framework for forecasting malaysian property prices. International Graduate Conference of Built Environment and Surveying Conference Proceedings (Volume 2), 325-332.

Sa'at, N.F. \& Adi Maimun, N.H. (2019b). Does artificial intelligence enhance house price forecasting accuracy? a literature review. International Journal of Real Estate Studies. 13(1), 74-78.

Suhaimi, N.A., Adi Maimun, N.H. \& Sa'at, N.F. (2021). Does rail transport impact house prices and rents? Planning Malaysia, 19(2), 141-149.

Selim, H. (2009). Determinants of house prices in Turkey: hedonic regression versus artificial neural network. Expert Systems with Applications, 36(2), 2843-2852.

Tabales, J.M.N., Ocerin, J.M.C.Y., \& Francisco, J.R.C. (2013). Artificial neural networks for predicting real estate prices. Revista De Metodos Cuantitativos Para La Economia $Y$ La Empresa, 15, 29-44.

Tan, T.H. (2010). Neighborhood preferences of House buyers: the case of Klang Valley, Malaysia. International Journal of Housing Markets \& Analysis, 4(1), 58-69.

Yalpir, S. (2014). Forecasting residential real estate values with AHP method and integrated GIS. People, Buildings and Environment Conference, An International Scientific Conference. 15-17 October, Kroměřž, Czech Republic.

Zihannudin, N.Z., Adi Maimun, N.H. \& Ibrahim, N.L. (2021). Brownfield sites and property market sensitivity. Planning Malaysia, 19(2), 121-130.

Received: $12^{\text {th }}$ July 2021. Accepted: $23^{\text {rd }}$ Sept 2021 